\title{
The Effect Of The Combination Of PMR (Progressive Muscle Relaxation) With Music On Ankle Brachial Index On Type II Diabetes Mellitus Patients
}

\author{
Denis Farida*, Retno Ayu. Yuliastuti \\ Sekolah Tinggi Ilmu Kesehatan Surabaya, Indonesia \\ *farida_denis@yahoo.co.id
}

\begin{abstract}
Along with the increasing welfare in developing countries, there is also an increase in degenerative diseases, one of which is diabetes mellitus. Diabetic patients with high sugar in the long term can worsen the body condition and damage other organs, one of the problems that often occurs is peripheral blood vessel disorders. The research objective was to determine the effect of the combination of PMR with music on the ankle-brachial index (ABI). Quasi-experimental research design with a pre-post-test control group design approach. The sample size was 32 respondents divided into 16 intervention groups and 16 control groups. The intervention group was given a combination of PMR with music for 1 month. The control group was not given an action. The instrument uses an observation sheet. The study used a paired t-test and independent t-test with $\alpha<0.05$.

The results showed the mean value (ABI). intervention group before exercise 0.74 and after exercise $0.90 \mathrm{mg} / \mathrm{dl}$. The control group before treatment has obtained an average (ABI). 0.77 and after treatment an average ABI was 0.75. Based on the independent $\mathrm{t}-$ test, blood sugar levels were obtained $\rho 0.000(\alpha<0.05)$. So that $\mathrm{H} 0$ is rejected, meaning that there is an effect of the combination of PMR and music on (ABI). The combination of PMR with music that is routinely performed can increase the ABI value.
\end{abstract}

Keywords : Diabetes Mellitus, PMR, Music, Ankle-Brachial Index 


\section{STRADA Jurnal Ilmiah Kesehatan}

DOI: $10.30994 /$ sjik.v9i2.400

ISSN: 2252-3847 (print); 2614-350X (online)

Vol.9 No.2 November 2020 Page.886-892

\section{BACKGROUND}

Along with the increasing welfare in this developing country, there is an increase in degenerative diseases, one of which is diabetes mellitus. Diabetes mellitus is a disease caused by the body's inability to carry out metabolism, be it protein metabolism, carbohydrate metabolism, and fat metabolism (Black \& Hawks, 2014). Uncontrolled diabetes or high blood sugar levels in the long term will harm other organs in the body. Examples of complications that can occur due to diabetes mellitus are disturbances in blood circulation, especially peripheral blood circulation. $60 \%$ of patients with diabetes mellitus have these complications (Black \& Hawks, 2014).

As for the report from the statistics of the International Diabetes Federation or (IDF), there were 382 million people diagnosed as DM sufferers in 2013 and by 2035 the number of DM sufferers is estimated to increase to 592 million people in the world who will suffer diabetes mellitus. When it is reported, the people of big cities such as Jakarta and Surabaya have reached almost $10 \%$ of the population who suffer from diabetes (Tandra, 2013). Population aged $\geq 15$ years based on the results of 2018 Riskesdas there was an increase in the number of DM sufferers by $2 \%$ (Infodatin, 2018). Based on the results of initial data collection, the number of patients visiting the Tenggilis Community Health Center in 2019 with a diagnosis of diabetes mellitus was 483 patients.

Uncontrolled diabetes such as an uncontrolled increase in blood sugar levels, frequent consumption of foods high in fat $\&$ cholesterol, can affect blood vessels, where this can cause complicating factors including atherosclerosis and atherosclerosis. Atherosclerosis can lead to peripheral artery disease or PAP, more than half of the amputations in the lower extremities are not caused because trauma is associated with complications due to diabetes mellitus such as sensory \& autonomic neuropathy, peripheral vascular disease (Black \& Hawks, 2014). Early prevention of peripheral vascular disease can be done with the examination of non-invasive blood vessels, namely by examining the ankle-brachial index or in short with ABI.

Several efforts can be done to prevent complications due to diabetes. Efforts that can be made include education related to nutritional diets and eating patterns, pharmacology or medicines according to doctor's recommendations, controlling blood sugar levels, and doing physical exercise. One of the physical exercises that can be applied every day and are easy to do is the combination of training progressive muscle relaxation (PMR) with music. Progressive muscle relaxation is an exercise that is carried out in two steps, the first step is to apply tension to a muscle group, the second is to stop the tension while the patient focuses attention on how the muscle relaxes, feels a relaxed sensation in the muscles ( Mashudi, 2011).

\section{METHODS}

This research uses the research quasi-experimental pre-test and post-test. The number of samples in this study was 32 which were divided into 2 groups, 16 intervention groups, and 16 control groups. The intervention group was given PMR combination training with music for 1 month. 


\section{STRADA Jurnal Ilmiah Kesehatan}

DOI: $10.30994 /$ sjik.v9i2.400

ISSN: 2252-3847 (print); 2614-350X (online)

Vol.9 No.2 November 2020 Page.886-892

RESULTS

Distribution of respondent characteristics based on gender, age, and duration of suffering from diabetes

Table 1 Frequency distribution of respondents based on age

\begin{tabular}{ccccc}
\hline & & Mean & SD & P-value \\
\hline Age of & intervention & 52.0 & 4.8 & 0.93 \\
& Control & 47.8 & 7.0 & \\
\cline { 2 - 5 }
\end{tabular}

Source: 2020 Primary data

Table 2 Frequency distribution of respondents based on gender

\begin{tabular}{ccrcc}
\hline Variable & \multicolumn{2}{c}{ Intervention } & \multicolumn{2}{c}{ Control } \\
& $\mathrm{N}$ & $\%$ & $\mathrm{n}$ & $\%$ \\
\hline Gender & & & & \\
Male & 2 & 12.5 & 5 & 31.2 \\
Female & 14 & 78.5 & 11 & 68.8 \\
\hline Total & 16 & 100 & 16 & 100 \\
\hline
\end{tabular}

Source: Primary data 2020

Table 3 Frequency distribution of respondents based on the duration of suffering from DM

\begin{tabular}{ccccc}
\hline Variable & & Mean & SD & P-Value \\
\hline Duration of DM & Intervention & 5.6 & 4.8 & 0.93 \\
& Control & 4.2 & 2.5 & \\
\cline { 2 - 5 }
\end{tabular}

Source: 2020 Primary Data

Table 4 Analysis of ABI Differences in the Intervention Group and the Control Group after Combined PMR Exercise with Music

\begin{tabular}{llllc}
\hline & & Mean & SD & P-Value \\
\hline ABI & Intervention & 0.90 & 0.06 & 0.011 \\
after & Control & 0.75 & 0.75 & \\
& & &
\end{tabular}

Source: Primary Data 2020

\section{DISCUSSION}

Ankle Brachial index or commonly abbreviated as ABI is prime tests are performed to detect or detect early conditions of peripheral blood circulation. In diabetes mellitus patients who cannot control or poor lifestyle patterns, in the long term, it will interfere with the state of circulation in the blood vessels. According to Grenon, 2009 the ABI value was interpreted into several parts, namely the ABI value $(0.90-1.30)$ normal, $(0.70-0.89)$ minimal, $(0.40$ - 0.69) moderate, $(<0.40)$ heavy. The results of the analysis of table 5.3 show that the average Ankle-Brachial index before the PMR combination exercise by listening to music in the intervention group, the value of the Ankle-Brachial index is in the minimal category or the peripheral blood circulation has a slight blockage and after being given exercise, the average Ankle-Brachial index is obtained. in the normal category. Whereas in the control group before and after the ABI value was obtained, namely in the 


\section{STRADA Jurnal Ilmiah Kesehatan}

DOI: $10.30994 /$ sjik.v9i2.400

ISSN: 2252-3847 (print); 2614-350X (online)

Vol.9 No.2 November 2020 Page.886-892

mild obstruction category. This shows that the combination of PMR with music can increase ABI to normal.

This stretching motion in PMR makes the muscles more active. The assumption is that when this exercise is done correctly and regularly it can increase the absorption of glucose by cells by increasing the intensity and duration of exercise, the breakdown of carbohydrates occurs more so that the patient's blood sugar level is close to normal or stable. A stable blood sugar level can increase the ABI value. The stretching movements contained in these 15 PMR movements stimulate the muscles to become more active and contract, in other words, it means that when this exercise is done correctly and regularly it can increase glucose absorption by cells by increasing the intensity and duration of exercise, the breakdown of carbohydrates occurs more., so that the patient's blood sugar level is close to normal or stable. A stable blood sugar level can increase the ABI value and vice versa. Diabetes mellitus patients who do not control blood sugar levels for a long time will be able to affect peripheral blood circulation, namely, the blood in the blood vessels will thicken as a result of glucose in the blood that cannot enter the cells. As a result, in a long time, the blood vessels will narrow, making it difficult for oxygen to reach the periphery to the tissue, this is what causes the ABI value to decrease from normal. Therefore, the five pillars of DM management must be carried out, considering the complications of diabetes mellitus if not handled early and seriously can cause disturbances in other organ functions and even lead to death.

Physical activity and stretching in the PMR Movement make blood vessels hyperemia. Hyperemia that occurs continuously will stimulate the blood vessels to become vasodilate by increasing the expression of nitric oxide synthase or abbreviated as (NOS) and releasing NO (Isral, 2014). Nitic oxide (NO) is a small reactive molecule known as a biomessenger. NO in the blood vessels causes relaxation of smooth muscle which functions as a regulator of blood flow and pressure and prevents platelet aggregation and adhesion. NO also helps in oxygen transport by expanding the walls of blood vessels thereby facilitating the transfer of gas to tissues and vice versa. The research was also conducted by Simanjuntak 2017, stating that an increase in blood sugar levels can affect blood viscosity and become platelet aggregability, which will stimulate the formation of microthrombi, and microvascular blockage, this will worsen the value of the anklebrachial index. This is also in line with research conducted by Putri 2019.

In this study, age, gender, and duration of suffering from diabetes were not significant, this could be influenced by several factors. The state of blood circulation can also be influenced by several factors, including food, activity. Often consume fatty foods, foods that are high in sugar, especially in diabetes patients. This is in line with the opinion of Black \& Hawks, 2014 which states that a person's daily activities can affect a person's blood circulation, where peripheral blood circulation can be determined by measuring ABI. For example, housewives do not necessarily have high activities such as washing, cooking, sweeping, and other household activities. In modern times, like today, many technologies help in household chores and 9 of the respondents said they used the help assistants of the household to help complete household activities. Even in this era of 4.0, everything is very sophisticated, without leaving the house without excessive activity, one can complete daily needs and activities. 


\section{STRADA Jurnal Ilmiah Kesehatan}

DOI: $10.30994 /$ sjik.v9i2.400

ISSN: 2252-3847 (print); 2614-350X (online)

Vol.9 No.2 November 2020 Page.886-892

PMR music combination can increase the value of ABI. Performing PMR accompanied by music can increase the feeling of relaxation in the patient so that it can stimulate endocrine hormones to be produced. When the patient is relaxed, brain activity and other bodily functions decrease as oxygen consumption decreases. So that the body's metabolic activity will also decrease, with a decrease in this metabolic activity it is expected that blood glucose levels in the body will be more stable. As the opinion (Aini \& Aridiana, 2016) stable blood sugar levels can prevent disturbances in peripheral blood circulation, where peripheral blood circulation can be determined by measuring the anklebrachial index. This shows that the PMR music combination can increase the ABI value in the normal category. Performing PMR accompanied by favorite music can increase the feeling of relaxation in the patient so that it can stimulate endocrine hormones to be produced. When the patient is relaxed, brain activity and other bodily functions decrease as oxygen consumption decreases. So that the body's metabolic activity will also decrease, with a decrease in this metabolic activity it is expected that blood glucose levels in the body will be more stable. As the opinion (Aini \& Aridiana, 2016) stable blood sugar levels can prevent disturbances in peripheral blood circulation, where peripheral blood circulation can be determined by measuring the ankle-brachial index

Apart from exercise, blood sugar levels are also a factor that can affect the anklebrachial index. Diabetes mellitus patients who do not control blood sugar levels for a long time will be able to affect peripheral blood circulation, namely, the blood in the blood vessels will thicken as a result of glucose in the blood that cannot enter the cells. As a result, in a long time, the blood vessels will narrow, making it difficult for oxygen to reach the periphery to the tissue, this is what causes the ABI value to decrease from normal. Therefore, the five pillars of DM management must be carried out, considering the complications of diabetes mellitus if not handled early and seriously can cause disturbances in other organ functions and even lead to death

Progressive muscle relaxation can reduce peripheral resistance and increase the elasticity of the blood vessels (Sucipto. 2014). muscle training Progressive can trigger an increase in NO (nitrite oxide) production by increasing the production of eNOS protein, this increase in eNos can trigger NO production (Isral, 2014). If the level of nitrite oxide increases, this will prevent blockages in the blood vessels or commonly known as atherosclerosis, when atherosclerosis has improved in the sense that the plaque attached to the walls of the blood vessels is getting thinner and thinner, this will facilitate blood supply. Increased blood and oxygen supply to the legs will keep the ABI value good.

\section{CONCLUSION}

The average ABI value before treatment in the intervention and control groups obtained $\mathrm{ABI}$ in the category of mild obstruction.

The average ABI value after treatment in the intervention group increased towards normal, while in the control group it remained in the mild obstruction category.

There are differences in the ankle-brachial index in the intervention and control groups after being given a combination of PMR with music, which means that the combination of PMR with music affects on increasing the ankle-brachial index to normal in type $2 \mathrm{DM}$ patients. 


\section{STRADA Jurnal Ilmiah Kesehatan}

DOI: $10.30994 /$ sjik.v9i2.400

ISSN: 2252-3847 (print); 2614-350X (online)

Vol.9 No.2 November 2020 Page.886-892

\section{SUGGESTIONS}

1. For Nursing Services

Nurses can advise patients with type 2 diabetes mellitus to do PMR combination exercise while listening to music every day in the morning with a duration of 15 minutes for 1 month.

2. For educational institutions

This research can be used as an evidence-based in providing additional knowledge on nursing disciplines.

\section{REFERENCE}

Aini \& Aridiana. 2016. Asuhan Keperawatan Sistem Endokrin dengan pendekatan NANDA NIC NOC. Jakarta: Salemba Medika

Black, M, J, and hawks, J, H. 2014. Keperawatan Medikal Bedah. Manajemen Klinis Untuk Hasil Yang Diharapkan. Singapore: Elseiver

Grenon Marlena, Gagnon Joel, Hsiang York. 2009. Ankle Brachial Index For Assesment of Peripheral Arterial Disease. The New England Journal of Medicine. Vol 36119.

Infodatin. 2014. Pusat dan data Informasi kementrian Kesehatan RI. http://www.depkes.go.id/folder/view/01/structure-publikasi-pusdatin-infodatin.html. Diakses tanggal Agustus 2019

Isral Ghozi. 2014. Hubungan Aktifitas Fisik Dengan kadar Nitric Oxide (NO) Plasma Pada Masyarakat di Kota Padang. Jurnal Kesehatan Andalas Vol 3:2 .

Mashudi. 2011. Pengaruh Progressive Muscle Relaxation Terhadap Kadar Gula Darah Pasien Diabetes Mellitus Tipe 2 Di Rumah Sakit Umum Daerah Raden Mattaher Jambi. Jakarta:FIK-UI

Putri, 2019. Pengaruh Terapi Relaksasi Otot Progresif Terhadap Perubahan Nilai Ankle Brachial Index dan Kadar Gula Darah Pada Lansia. Surabaya: Universitas Catholic Widya Mandala

Simanjutak galvani Volta. 2017 Pengaruh latihan Relaksasi Otot Progressive Terhadap Kadar Gula darah \& Ankle Brachial Index pada pasien Diabetes MellitusTipe II. Medan:Universitas Sari Mutiara Indonesia

Sucipto. 2014. Pengerauh Teknik Relaksasi Otot Progresif Terhadap Tekanan darah Pada lansia Dengan Hipertensi Di Desa Karangbendo banguntapan Bantul Yogjakarta. Jakarta : FKUI

Suwardianto H (2017) Pengetahuan, Sikap Dan Perilaku Pencegahan Dekubitus Pada Keluarga Dengan Imobilisasi. Pros. Semin. Nas. dan Work. Publ. Ilm.

Suwardianto H, YC A (2016) Kemandirian Fungsional Lansia Diabetes Melitus Di Kelurahan Bangsal Kota Kediri. J. STIKES RS Baptis Kediri 9: 


\section{STRADA Jurnal Ilmiah Kesehatan}

DOI: $10.30994 /$ sjik.v9i2.400

ISSN: 2252-3847 (print); 2614-350X (online)

Vol.9 No.2 November 2020 Page.886-892

Suwardianto, H. (2018). Level Of Perception Emergency Skills In Youth Red Cross. JOURNAL OF NURSING PRACTICE, 2(1), 17-24.

Suwardianto, H., \& Sari, D. A. K. W. (2019). Pain Level in Critical Patients With Sleep Hygiene Care In Intensive Care Unit. Journal Of Nursing Practice, 3(1 SEArticles). https://doi.org/10.30994/jnp.v3i1.61

Tandra, Hans. 2013. Life Healthy with Diabetes - Diabetes Mengapa \& Bagaimana. Yogyakarta: Rapha Publishing 